\title{
Pretreatment of Color Filter Wastewater towards Biodegradable by Fresnel-Lens-Assisted Solar $\mathrm{TiO}_{2}$ Photocatalysis
}

\author{
Wen-Shiuh Kuo and Min-Tian Li \\ Department of Safety, Health, and Environmental Engineering, National United University, Miao-Li 360, Taiwan \\ Correspondence should be addressed to Wen-Shiuh Kuo, wsk@nuu.edu.tw
}

Received 20 July 2012; Revised 16 August 2012; Accepted 16 August 2012

Academic Editor: Jiaguo Yu

Copyright ( $) 2012$ W.-S. Kuo and M.-T. Li. This is an open access article distributed under the Creative Commons Attribution License, which permits unrestricted use, distribution, and reproduction in any medium, provided the original work is properly cited.

\begin{abstract}
The pretreatment of color filter wastewater towards biodegradable by Fresnel-lens-enhanced solar $\mathrm{TiO}_{2}$ photocatalytic process was investigated. The experimental design of response surface methodology (RSM) was employed to assess the effect of critical process parameters (including initial $\mathrm{pH}, \mathrm{TiO}_{2}$ dosage, and reaction time) on pretreatment performance in terms of $\mathrm{BOD} 5 / \mathrm{COD}$, COD and TOC removal efficiency. Appropriate reaction conditions were established as an initial $\mathrm{pH}$ of 7.5 , a $\mathrm{TiO}_{2}$ dosage of $1.5 \mathrm{~g} / \mathrm{L}$ with a reaction time of $3 \mathrm{~h}$ for increasing the $\mathrm{BOD}_{5} / \mathrm{COD}$ ratio to 0.15 , which implied that the treated wastewater would be possibly biodegradable. Meanwhile, the efficiency of COD and TOC removals reached $32.9 \%$ and $24.4 \%$, respectively. With the enhancement of Fresnel lens, the required reaction time for improving the biodegradability of wastewater to 0.15 was $1 \mathrm{~h}$ only. Moreover, the efficiency of COD and TOC removals was promoted to $37.4 \%$ and $25.8 \%$, respectively. This could be mainly due to the concentrated effect of Fresnel lens for solar energy, including an increase of 2 times of solar irradiation and a raising of $15-20^{\circ} \mathrm{C}$ of wastewater temperature. Consequently, solar $\mathrm{TiO}_{2}$ photocatalytic process with the use of a PMMA Fresnel lens could offer an economical and practical alternative for the pretreatment of industry wastewater containing diversified biorefractory pollutants with a high concentration of COD such as color filter wastewater.
\end{abstract}

\section{Introduction}

Organic wastewater from color filter industry generally contains so many residuals such as TMAH $\left(\mathrm{C}_{4} \mathrm{H}_{13} \mathrm{NO}\right)$, PGMEA $\left(\mathrm{C}_{6} \mathrm{H}_{12} \mathrm{O}_{3}\right)$, acrylic resin, and pigments, and it is variable in composition and strength at different stages of process. In the presence of biorefractory organic matter, the effluent is usually characterized by its high chemical oxygen demand (COD) and low biodegradability generally expressed as a ratio of biological oxygen demand at day $5\left(\mathrm{BOD}_{5}\right)$ to $\mathrm{COD}$, that is, $\mathrm{BOD}_{5} / \mathrm{COD}$. Advanced oxidation processes (AOPs) have been previously described as a promising option to remove persistent pollutants from contaminated water [1] when conventional water treatment processes are not efficient enough. AOPs are able to produce a highly reactive, nonspecific oxidant, mainly hydroxyl radicals $\left({ }^{\bullet} \mathrm{OH}\right)$. The hydroxyl radical possesses inherent properties that enable it to attack refractory organic pollutants in water to achieve a complete mineralization. However, the production of photons with artificial light sources requires significant electrical energy demand and UV lamp consumption, which result in a high operation cost in AOPs [2]. Alternatively, solar energy is essentially unlimited and its utilization is ecologically benign. In the wastewater treatment sector, solar technology has been extensively used as an alternative to UV lamps to reduce the operation cost in AOPs [3]. In particular, $\mathrm{TiO}_{2}$ photocatalysis (as shown in (1)-(3)) using solar irradiation has been used as an economically viable process and has attracted great interest in the recent years [4-6]:

$$
\begin{gathered}
\mathrm{TiO}_{2} \stackrel{h v(\lambda<382 \mathrm{~nm})}{\longrightarrow} h_{v b}^{+}+e_{c b}^{-} \\
h_{v b}^{+}+\mathrm{H}_{2} \mathrm{O} \longrightarrow \cdot \mathrm{OH}+\mathrm{H}^{+} \\
h_{v b}^{+}+\mathrm{OH}^{-} \longrightarrow \cdot \mathrm{OH}
\end{gathered}
$$

However, solar $\mathrm{TiO}_{2}$ photocatalysis was usually carried out by using solar irradiation directly, resulting in a lower absorption and utilization of solar energy $[7,8]$. To improve the efficiency of solar $\mathrm{TiO}_{2}$ photocatalysis, it is necessary 
TABle 1: Physical and chemical properties of color filter wastewater.

\begin{tabular}{lc}
\hline Characteristic & Values \\
\hline $\mathrm{pH}$ & $9.8 \sim 10.2$ \\
$\mathrm{COD}, \mathrm{mg} / \mathrm{L}$ & $924 \sim 960$ \\
$\mathrm{BOD}_{5}, \mathrm{mg} / \mathrm{L}$ & $22 \sim 51$ \\
$\mathrm{BOD}_{5} / \mathrm{COD}$ & $0.02 \sim 0.05$ \\
$\mathrm{TOC}, \mathrm{mg} / \mathrm{L}$ & $280 \sim 303$ \\
$\mathrm{SS}, \mathrm{mg} / \mathrm{L}$ & $0.3 \sim 1.9$ \\
$\mathrm{TS}, \mathrm{mg} / \mathrm{L}$ & $1080 \sim 1160$ \\
$\mathrm{Color}(\mathrm{ADMI}$ value $)$ & $1540 \sim 1600$ \\
$\mathrm{TMAH}, \mathrm{mg} / \mathrm{L}$ & $3.2 \sim 3.3$ \\
$\mathrm{Cl}^{-}, \mathrm{mg} / \mathrm{L}$ & $1.8 \sim 2.0$ \\
$\mathrm{NO}_{3}{ }^{-}, \mathrm{mg} / \mathrm{L}$ & $4.8 \sim 5.0$ \\
$\mathrm{SO}_{4}{ }^{2-}, \mathrm{mg} / \mathrm{L}$ & $1.1 \sim 1.2$ \\
$\mathrm{NH}_{4}{ }^{+}, \mathrm{mg} / \mathrm{L}$ & $0.7 \sim 0.8$ \\
\hline
\end{tabular}

to concentrate and maximize solar energy utilization in the process. Moreover, the combination of solar $\mathrm{TiO}_{2}$ photocatalysis as a preliminary treatment, followed by an inexpensive biological process, seems to be a more attractive option for biorefractory organic wastewater.

In this study, pretreatment of color filter wastewater towards biodegradable using solar $\mathrm{TiO}_{2}$ photocatalysis enhanced by a high-concentrating Fresnel lens was investigated. A factorial design according to response surface methodology (RSM) was employed to optimize the reaction conditions of critical process parameters (including initial $\mathrm{pH}$ of wastewater, $\mathrm{TiO}_{2}$ dosage, and reaction time) to reach a biodegradable degree of color filter wastewater. Moreover, the effect of Fresnel lens on treatment performance in terms of COD degradation efficiency, mineralization efficiency, and biodegradability $\left(\mathrm{BOD}_{5} / \mathrm{COD}\right)$ of color filter wastewater was examined.

\section{Material and Methods}

2.1. Materials. The color filter wastewater used in this study was obtained from an electrooptical industry plant located in Hsin-Chu, Taiwan, during 2009-2010. The characteristics of color filter wastewater are shown in Table 1. Basically, the color filter wastewater has the properties of high COD (924-960 mg/L), high TOC (280-303 mg/L), and low biodegradability (BOD $/$ /COD: $0.02-0.05)$. $\mathrm{TiO}_{2}$ powder (mainly anatase form, mean particle size: $30 \mathrm{~nm}$, BET surface area: $50 \pm 15 \mathrm{~m}^{2} / \mathrm{g}$ ) from Degussa Co. (Frankfurt, Germany) was used in this study. All other chemicals used in this study were analytical grade and used as received.

2.2. Procedures. All experiments were carried out in a batch mode. A $1 \mathrm{~L}$ glass beaker containing $200 \mathrm{~mL}$ of color filter wastewater was used and maintained at a preset temperature in a water bath during the experiments. A 3 factors $* 3$ levels Box-Behnken experimental design [9] with three replicates at center point according to the methodology of response surface as shown in Table 2 was performed to examine
TABLE 2: Experimental range and levels of the process parameters in this study.

\begin{tabular}{lcccc}
\hline & Factor & \multicolumn{4}{c}{ Range and level } \\
\hline Independent variable & & $-\mathbf{1}$ & $\mathbf{0}$ & $+\mathbf{1}$ \\
Initial pH & $X_{1}$ & 5 & 7.5 & 10 \\
$\mathrm{TiO}_{2}$ dose, $\mathrm{g} / \mathrm{L}$ & $X_{2}$ & 0.5 & 1.0 & 1.5 \\
Reaction time, $\mathrm{hr}$ & $X_{3}$ & 1 & 2 & 3 \\
\hline$Y$ (response) $-\mathrm{BOD}_{5} / \mathrm{COD}$ & \multicolumn{5}{r}{} \\
\hline
\end{tabular}

the influence of three critical process parameters (viz., initial $\mathrm{pH}, \mathrm{TiO}_{2}$ dosage and reaction time) on the biodegradability, COD and TOC degradation of wastewater. Moreover, the regression analysis of Minitab R14 software (Minitab Co., USA) was used to figure out the reaction conditions for improving the biodegradability of wastewater. At the RSM runs, the initial $\mathrm{pH}$ of wastewater was adjusted to the desired $\mathrm{pH}$ by adding $1 \mathrm{~N} \mathrm{H}_{2} \mathrm{SO}_{4}$. The wastewater was then placed into the photoreactor and irradiated by a $1500 \mathrm{~W}$ Xe lamp in an ATLAS Suntest CPS+ solar simulator (ATLAS Co., USA) emitting artificial solar light with a spectral distribution resembling the solar spectrum $(300-800 \mathrm{~nm})$ in which the $\mathrm{UV}_{280-400} \mathrm{~nm}$ intensity is around $66.5 \pm 0.5 \mathrm{~W} / \mathrm{m}^{2}$. In addition, the wastewater was maintained at $25 \pm 0.5^{\circ} \mathrm{C}$ in a water bath. During the experiments, the $\mathrm{pH}$ of the solution was monitored using a pH meter (SP-701LI 120, Suntex Co., Taiwan) equipped with a glass electrode. Samples were withdrawn from the reactor at preset time intervals and then tested for COD, TOC, and $\mathrm{BOD}_{5}$.

As the appropriate values of the process parameters were developed on the basis of RSM application and related regression equation of biodegradability, a Fresnel lens made of PMMA (thickness: $2 \mathrm{~mm}$, pitch: $0.5 \mathrm{~mm}$, facet depth: $0.2 \mathrm{~mm}$, Fresnel circles: 395) was added into solar $\mathrm{TiO}_{2}$ photocatalytic system with a distance of $16 \mathrm{~cm}$ above the level of wastewater in a clear sky condition to investigate the effect of Fresnel lens. The solar irradiation was measured with a LI250 radiation indicator (LI-COR Co., USA) of pyranometer LI-200SA and a UV $280-400 \mathrm{~nm}$ detector of PMA 2100 (Solar Light Co., USA). The irradiated solar irradiation during the experimental run with Fresnel lens was in the range of 900 $1000 \mathrm{~W} / \mathrm{m}^{2}\left(\mathrm{UV}_{280-400 \mathrm{~nm}}: 52.4-57.4 \mathrm{~W} / \mathrm{m}^{2}\right)$. In addition, two blank experiments including direct photolysis reaction and adsorption on $\mathrm{TiO}_{2}$ only under the experimental conditions of this study were performed. The result indicated that the COD and TOC removal efficiency of color filter wastewater was less than $1 \%$, which implied that the removal of organic pollutants of color filter wastewater due to these effects was negligible in this study.

\subsection{Analysis}

2.3.1. Chemical Oxygen Demand (COD) Measurement. COD of solution via a DR 4000 photometer ( $\mathrm{HACH}$ Co., USA) by using a $\mathrm{K}_{2} \mathrm{Cr}_{2} \mathrm{O}_{7}$ as the reacting reagent was measured in order to understand the changes on degree of oxidation for color filter wastewater. 
2.3.2. Total Organic Carbon (TOC) Measurement. TOC of solution was measured by using a Shimadzu VCPH analyzer (Shimadzu Co., Japan) in order to know the amount of organics in color filter wastewater degraded to $\mathrm{CO}_{2}$ during oxidation.

2.3.3. $\mathrm{BOD}_{5}$ Measurement. $\mathrm{BOD}_{5}$ test was measured according to the procedures described in Standard methods 10 [Section 5210D, 10].

The bacteria $(2000 \sim 4000 \mathrm{mgMLSS} / \mathrm{L})$ used in this test were obtained from a local activation sludge system, operating at industrial wastewater treatment plant. The data showed that the $\mathrm{BOD}_{5}$ value of untreated color filter wastewater in this study was in the range of $0.02 \sim 0.05$, indicating that the color filter wastewater was hardly biodegradable.

\section{Results and Discussion}

3.1. Effect of Initial $\mathrm{pH}$ and Dosage of $\mathrm{TiO}_{2}$. Figure 1 displays the two-dimensional contour plots for the biodegradability $\left(\mathrm{BOD}_{5} / \mathrm{COD}\right), \mathrm{COD}$, and TOC degradation of color filter wastewater as a function of initial $\mathrm{pH}$ and concentration of $\mathrm{TiO}_{2}$. As shown in Figure 1, when the $\mathrm{pH}$ of wastewater was varied from 10 (the original $\mathrm{pH}$ of wastewater) to 5 at the same $\mathrm{TiO}_{2}$ dosage, the biodegradability of wastewater decreased with decreasing initial $\mathrm{pH}$ of wastewater to around a $\mathrm{pH}$ of 7.5 and then gradually increased with decreasing initial $\mathrm{pH}$ of wastewater to $\mathrm{pH}$ 5. This phenomenon was also observed in the degradation of COD and TOC in all the $\mathrm{TiO}_{2}$ concentration range studied. This can be explained by the surface charge of $\mathrm{TiO}_{2}$ as a function of $\mathrm{pH}$. The zero point of charge (ZPC) for $\mathrm{TiO}_{2}-\mathrm{P} 25$ is around $\mathrm{pH}$ 6.3-6.8 [11]. Therefore, at more acidic $\mathrm{pH}$ values $\left(\mathrm{pH}<\mathrm{pH}_{\mathrm{ZPC}}\right)$, the $\mathrm{TiO}_{2}$ surface is positively charged as expressed by (4) and at alkaline $\mathrm{pH}$, the surface $\left(\mathrm{pH}>\mathrm{pH}_{\mathrm{ZPC}}\right)$ is negatively charged as expressed by (5) $[12,13]$. Therefore, at $\mathrm{pH}$ values below 6.3 , the adsorption of wastewater is favourable due to the electrostatic attraction between the organic pollutants of wastewater and positively charged $\mathrm{TiO}_{2}$ on the surface, leading to a better efficiency with the ${ }^{\bullet} \mathrm{OH}$ generated on the surface of $\mathrm{TiO}_{2}$. A similar phenomenon was found in the study of Xiang et al. [14]. Moreover, the study of Wang et al. [15] indicated that the positively charged $\mathrm{TiO}_{2}$ could prompt the transfer of photoinduced electrons to the oxygen adsorbed on the surface of $\mathrm{TiO}_{2}$. Consequently, the superoxide ion would be produced as shown in (6) and the recombination of electron hole on the surface of $\mathrm{TiO}_{2}$ would be probably inhibited:

$$
\begin{gathered}
\mathrm{TiOH}+\mathrm{H}^{+} \longrightarrow \mathrm{TiOH}_{2}^{+} \\
\mathrm{TiOH}+\mathrm{OH}^{-} \longrightarrow \mathrm{TiO}^{-}+\mathrm{H}_{2} \mathrm{O} \\
\mathrm{e}^{-}+\mathrm{O}_{2} \longrightarrow \mathrm{O}_{2}^{\cdot-}
\end{gathered}
$$

As the $\mathrm{pH}$ was above 6.8 , the organic pollutants of wastewater were subjected to electrostatic repulsion between themselves and the negative surface of $\mathrm{TiO}_{2}$. Hence, the adsorption of the organic pollutants of wastewater is less, leading to a decrease in degradation efficiency. Similar results were also observed in the $\mathrm{TiO}_{2}$ photocatalytic degradation of a power station effluent [16] and the adsorption of Congo red on the surface of $\mathrm{NiO}$ [17]. Nevertheless, Barka et al. [18] pointed out that more $\mathrm{OH}^{-}$may react with the holes generated from the photoexcitation of $\mathrm{TiO}_{2}$ and produced more ${ }^{\bullet} \mathrm{OH}$ radicals as described by (3), leading to a higher degradation efficiency. Hence, the biodegradability and degradation efficiency of color filter wastewater treated in the alkaline condition ( $\mathrm{pH}$ 10) was found to be higher than those treated in the neutral $\mathrm{pH}$. In general, the biodegradability and degradation efficiency of color filter wastewater was in the order of pH $5>$ pH $10>$ pH 7.5 under all $\mathrm{TiO}_{2}$ concentration range studied.

On the other hand, as shown in Figure 1, the concentration of $\mathrm{TiO}_{2}$ also showed an obvious effect on the biodegradability and degradation efficiency of color filter wastewater. Ordinarily, more catalyst will substantially result in more generation of hydroxyl radicals until an optimum catalyst concentration is achieved. Hence, the results showed that, under all $\mathrm{pH}$ range studied (5-10), the increase of catalyst concentration from 0.5 to $1.5 \mathrm{~g} / \mathrm{L}$ increased the degradation efficiency. This fact may be due to the increase in the number of organic pollutants adsorbed and more oxidation of organics [19].

In addition, the experimental results allow the development of a second-order polynomial multiple regression equation as described by (7), which could be used to assess the effect of critical process parameters (viz., initial $\mathrm{pH}, \mathrm{TiO}_{2}$ dosage and reaction time) on pretreatment performance in terms of the biodegradability of wastewater. The regression model had a high value of coefficient of determination $\left(r^{2}>0.96\right)$. This implies that the process efficiency could be predicted well by the second order polynomial regression equations under the conditions studied. Moreover, a neutral $\mathrm{pH}$ must be considered for a better operation of the following biological treatment. Accordingly, an appropriate reaction condition was established as an initial $\mathrm{pH}$ value of 7.5, a $\mathrm{TiO}_{2}$ dosage of $1.5 \mathrm{~g} / \mathrm{L}$ with a reaction time of $3 \mathrm{~h}$ for increasing the ratio of $\mathrm{BOD}_{5} / \mathrm{COD}$ ratio to 0.15 , which means the treated wastewater reaching a possibly biodegradable level [20]:

$$
\begin{aligned}
Y_{\mathrm{BOD} 5 / \mathrm{COD}}= & 0.166-0.010 X_{1}+0.035 X_{2} \\
& +0.027 X_{3}-0.033 X_{1}^{2}-0.026 X_{2}^{2} \\
& -0.051 X_{3}^{2}-0.027 X_{1} X_{2}-0.015 X_{1} X_{3} \\
& -0.003 X_{2} X_{3}, \quad r^{2}=0.962 .
\end{aligned}
$$

3.2. Effect of Fresnel Lens. Table 3 showed the effect of Fresnel lens on the degradation efficiency and biodegradability of color filter wastewater under the reaction condition with an initial $\mathrm{pH}$ of 7.5 and $\mathrm{TiO}_{2}$ dosage of $1.5 \mathrm{~g} / \mathrm{L}$. It was found that the concentrating effect of Fresnel lens for solar energy could result in an increase of 2 times of solar light intensity as indicated by an increase in $\mathrm{UV}_{280-400 \mathrm{~nm}}$ intensity from $54.9 \mathrm{~W} / \mathrm{m}^{2}$ to $110.3 \mathrm{~W} / \mathrm{m}^{2}$, accompanied with a raising of 
TABLE 3: Effect of Fresnel lens on the degradation efficiency and biodegradability of color filter wastewater.

\begin{tabular}{|c|c|c|c|c|c|c|}
\hline $\begin{array}{l}\text { Solar light source and reaction } \\
\text { time }\end{array}$ & $\begin{array}{c}\mathrm{UV}_{280-400 \mathrm{~nm}} \\
\text { Intensity, } \mathrm{W} / \mathrm{m}^{2}\end{array}$ & $\begin{array}{c}\text { Wastewater } \\
\text { temperature, }{ }^{\circ} \mathrm{C}\end{array}$ & COD removal, $\%$ & TOC removal, \% & AOS & $\mathrm{BOD}_{5} / \mathrm{COD}$ \\
\hline Solar light + Fresnel lens, $1 \mathrm{~h}$ & 110.3 & $35-45$ & 37.4 & 25.8 & 0.01 & 0.150 \\
\hline Suntest $500 \mathrm{~W} / \mathrm{m}^{2}, 1 \mathrm{~h}$ & 66.5 & 25 & 25.9 & 20.3 & -0.40 & 0.112 \\
\hline Suntest $500 \mathrm{~W} / \mathrm{m}^{2}, 2 \mathrm{~h}$ & 66.5 & 25 & 29.1 & 22.6 & -0.15 & 0.120 \\
\hline Suntest $500 \mathrm{~W} / \mathrm{m}^{2}, 3 \mathrm{~h}$ & 66.5 & 25 & 32.9 & 24.4 & -0.02 & 0.145 \\
\hline
\end{tabular}

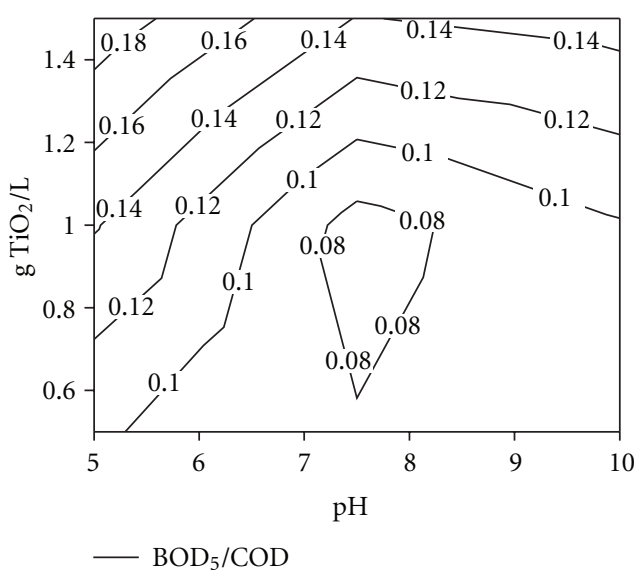

(a)

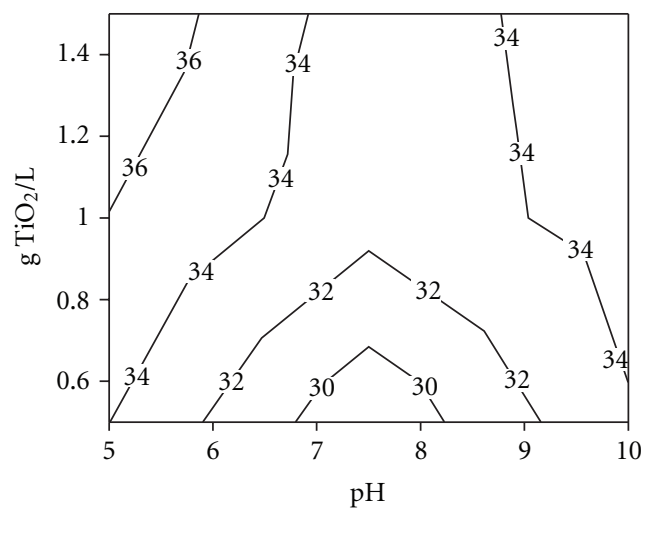

COD removal (\%)

(b)

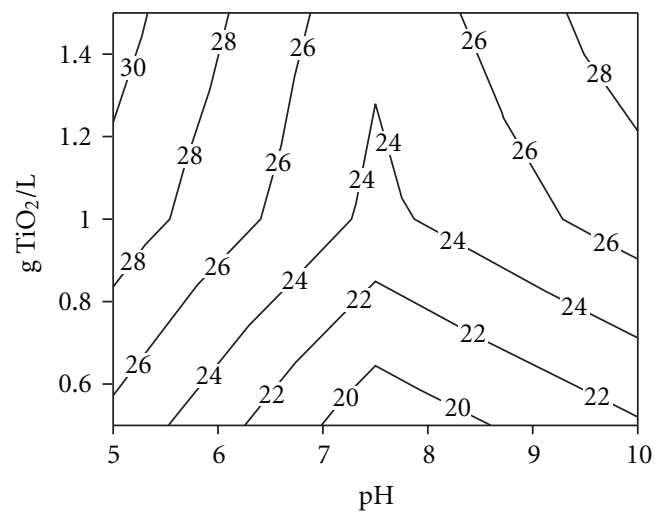

TOC removal (\%)

(c)

FIGURE 1: Contour of the biodegradability (a) and degradation efficiency (b) and (c) of color filter wastewater as a function of initial pH and $\mathrm{TiO}_{2}$ dosage (reaction time: $3 \mathrm{~h}$ ).

heat irradiation in terms of $15 \sim 20^{\circ} \mathrm{C}$ increase in wastewater temperature in this study. Consequently, a $37.4 \%$ of COD and a $25.8 \%$ of TOC degradation of color filter wastewater were achieved in a reaction time of $1 \mathrm{~h}$ with the assistance of Fresnel lens, in contrast to a $32.9 \%$ of COD and a $24.4 \%$ of TOC degradation in $3 \mathrm{~h}$ reaction by an artificial solar irradiation with an $\mathrm{UV}_{280-400 \mathrm{~nm}}$ intensity of $66.5 \mathrm{~W} / \mathrm{m}^{2}$.

Moreover, the degree of oxidation of color filter wastewater during solar photocatalysis could significantly affect the biodegradability of solution. The average oxidation state (AOS) of organic carbon could be used to monitor the change in the degree of oxidation of pollutants [1]. The average oxidation state of the organic carbon was calculated by.

$$
\mathrm{AOS}=4-1.5 \times \frac{\mathrm{COD}}{\mathrm{TOC}},
$$

in which the unit of COD and TOC is $\mathrm{mg} / \mathrm{L}$. The AOS value indicates how chemical substances in the effluent become more oxidized. A higher AOS value implies a higher degree of oxidation. Theoretically, the AOS has a value of +4 for $\mathrm{CO}_{2}$, the most oxidized state of $\mathrm{C}$, and -4 for $\mathrm{CH}_{4}$, the most reduced state of carbon. As shown in Table 3, the AOS values increased from -0.73 for untreated color filter wastewater 


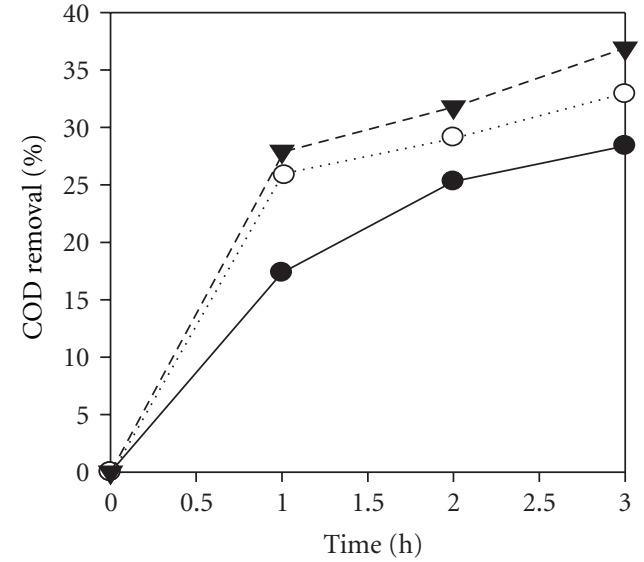

(a)

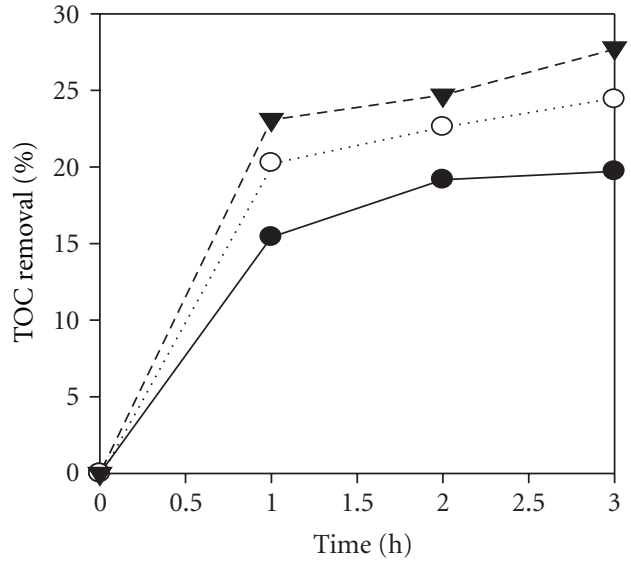

(b)

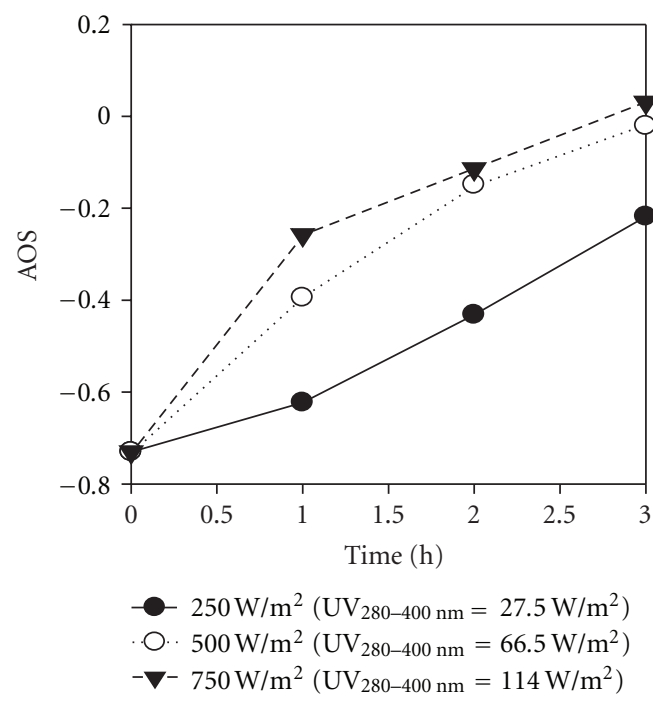

(c)

FIGURE 2: Effect of solar light intensity on the degradation of color filter wastewater (wastewater temperature: $25 \pm 0.5^{\circ} \mathrm{C}$ ).

to 0.01 and -0.42 for treated color filter wastewater at a reaction time of $1 \mathrm{~h}$ with and without using Fresnel lens, respectively. This result implied that a higher degree of oxidation happened, leading to a further improvement in the biodegradability of color filter wastewater in Fresnel-lensassisted system. The required reaction time to reach the criteria of a possible biodegradability of wastewater, which a $\mathrm{BOD}_{5} / \mathrm{COD}$ value of 0.15 was usually selected, and it was, therefore much less for the Fresnel-lens-assisted system.

Basically, the degradation efficiency of wastewater increased with increasing light intensity in the $\mathrm{TiO}_{2}$ photocatalytic process [21]. As shown in Figure 2, the result illustrated that the higher the solar light intensity, the higher the COD and TOC degradation was. A 10\% increase of the COD and TOC degradation was observed with raising solar light intensity from $250\left(\mathrm{UV}_{280-400 \mathrm{~nm}}: 27.5 \mathrm{~W} / \mathrm{m}^{2}\right)$ to $750 \mathrm{~W} / \mathrm{m}^{2}$ $\left(\mathrm{UV}_{280-400 \mathrm{~nm}}: 114 \mathrm{~W} / \mathrm{m}^{2}\right)$. This could be becuase a higher light irradiation increased the generation of electron-hole pairs and then produced more oxidizing species such as ${ }^{\bullet} \mathrm{OH}$ radical. A similar phenomenon was observed in the study of Liu et al. [22]. Their result indicated that the TOC degradation efficiency of Acid Yellow 17 solution increased from $5.1 \%$ to $53.2 \%$ as the intensity of UV light increased from 12.4 to $31.5 \mathrm{~W} / \mathrm{m}^{2}$, indicating a positive effect of increasing light irradiation.

Furthermore, the degradation efficiency of wastewater probably increased with increasing the temperature of wastewater. The study of Daneshvar et al. [23] indicated that the effect of wastewater temperature on the degradation efficiency of wastewater may not be significant because the adsorption capability of $\mathrm{TiO}_{2}$ may decrease and the recombination of electron hole may accelerate. However, the study of Barka et al. [24] found that the degradation efficiency of dye wastewater increased with raising the wastewater temperature from 20 to $40^{\circ} \mathrm{C}$ due to the enhanced motivation energy of wastewater, leading to increasing the frequency of collision between pollutants and $\cdot \mathrm{OH}$. As shown in Figure 3, a $10 \%$ increase of the COD and TOC degradation was 


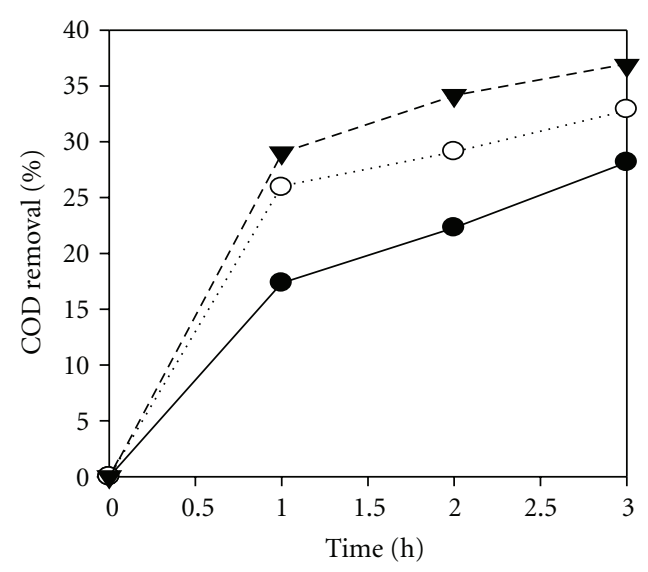

(a)

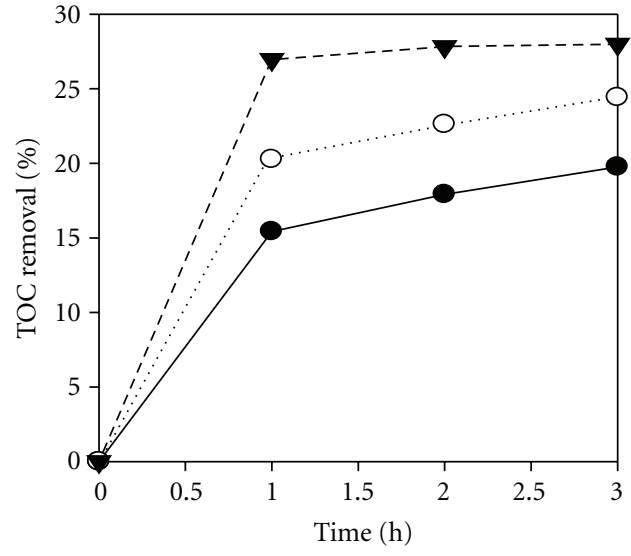

(b)

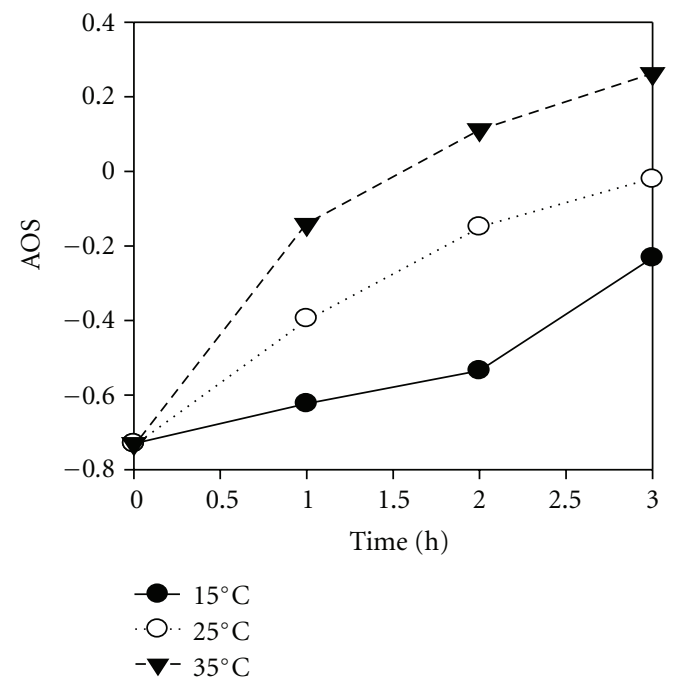

(c)

FIGURE 3: Effect of wastewater temperature on the degradation of color filter wastewater (solar light intensity: $500 \mathrm{~W} / \mathrm{m}^{2}\left(\mathrm{UV}_{280-400 \mathrm{~nm}}\right.$ : $\left.\left.66.5 \mathrm{~W} / \mathrm{m}^{2}\right)\right)$.

observed with raising wastewater temperature from 15 to $35^{\circ} \mathrm{C}$. Similarly, the results of Lin and Lee [25] illustrated that the degradation efficiency of MX-5B dye wastewater improved $15 \%$ while the temperature of water was increased from 22 to $40^{\circ} \mathrm{C}$ in a $\mathrm{TiO}_{2}$ photocatalytic process. This is because a higher water temperature increased the reaction rate between ${ }^{\circ} \mathrm{OH}$ and organic molecules. Accordingly, two promotion effects were found with the assistance of Fresnel lens. First, the increase of solar light irradiation could enhance the excitation of electron-hole and then persistent promotion of $\bullet \mathrm{OH}$ production. Secondly, the raise of water temperature would be higher due to the effect of solar heat irradiation, which provides additional positive effect on the performance of solar photocatalytic process. By the way, quantitative determination of the concentration of hydroxyl radicals produced during photocatalysis may provide more solid explanation for the promotion effect with the assistance of Fresnel lens. Xiang et al. [26] reported that the photoluminescence $(\mathrm{PL})$ technique using coumarin as a probe molecule of $\bullet \mathrm{OH}$ radicals is an effectively probing method for indirect determination of hydroxyl radical concentration. However, hydroxyl radicals had a short lifetime and high reactivity influencing its detection efficiency. Newton and Milligan [27] had reported that the trapping efficiency of ${ }^{\bullet} \mathrm{OH}$ formed in the $\mathrm{TiO}_{2}$ photocatalysis was about $5-11 \%$ even by the $\mathrm{PL}$ technique. Therefore, though the measurement of ${ }^{\bullet} \mathrm{OH}$ concentration was not performed in this study, the promotion effect of Fresnel lens on solar $\mathrm{TiO}_{2}$ photocatalysis is still clear according to the results, namely, the increase of biodegradability, COD, and TOC removal efficiency of wastewater.

To quantitatively analyze the effect of solar light intensity and solar heat irradiation in terms of wastewater temperature on the degradation of color filter wastewater, a pseudo-firstorder model was applied to obtain the rate constants as shown in Tables 4 and 5, respectively. It was found that both the COD and TOC degradation rate of color filter wastewater increased significantly with increasing solar light intensity and wastewater temperature. The effect of wastewater temperature was more obvious than that of solar light intensity on the degradation rate of color filter wastewater. 
TABLE 4: Effect of solar light intensity on the degradation rate constant of color filter wastewater ${ }^{\mathrm{a}}$.

\begin{tabular}{lcc}
\hline Solar Light Intensity & ${ }^{\mathrm{b}} k_{\mathrm{COD}}, \mathrm{hr}^{-1}$ & ${ }^{\mathrm{c}} k_{\mathrm{TOC}}, \mathrm{hr}^{-1}$ \\
\hline $250 \mathrm{~W} / \mathrm{m}^{2}\left(\mathrm{UV}_{280-400 \mathrm{~nm}}: 27.5 \mathrm{~W} / \mathrm{m}^{2}\right)$ & 0.154 & 0.118 \\
$500 \mathrm{~W} / \mathrm{m}^{2}\left(\mathrm{UV}_{280-400 \mathrm{~nm}}: 66.5 \mathrm{~W} / \mathrm{m}^{2}\right)$ & 0.197 & 0.147 \\
$750 \mathrm{~W} / \mathrm{m}^{2}\left(\mathrm{UV}_{280-400 \mathrm{~nm}}: 114 \mathrm{~W} / \mathrm{m}^{2}\right)$ & 0.218 & 0.165 \\
\hline
\end{tabular}

${ }^{\mathrm{a}}$ Wastewater temperature: $25 \pm 0.5^{\circ} \mathrm{C}$.

${ }^{\mathrm{b}} k_{\mathrm{COD}}$ : pseudo-first-order rate constant based on the degradation of COD in solution.

${ }^{c} k_{\text {TOC }}$ : pseudo-first-order rate constant based on the degradation of TOC in solution.

TABle 5: Effect of water temperature on the degradation rate constant of color filter wastewater ${ }^{\mathrm{a}}$.

\begin{tabular}{lcc}
\hline Wastewater temperature & ${ }^{\mathrm{a}} k_{\mathrm{COD}}, \mathrm{hr}^{-1}$ & ${ }^{\mathrm{b}} k_{\mathrm{TOC}}, \mathrm{hr}^{-1}$ \\
\hline $15^{\circ} \mathrm{C}$ & 0.140 & 0.116 \\
$25^{\circ} \mathrm{C}$ & 0.197 & 0.147 \\
$35^{\circ} \mathrm{C}$ & 0.235 & 0.193 \\
\hline
\end{tabular}

${ }^{a}$ solar light intensity: $500 \mathrm{~W} / \mathrm{m}^{2}\left(\mathrm{UV}_{280-400 \mathrm{~nm}}: 66.5 \mathrm{~W} / \mathrm{m}^{2}\right)$.

${ }^{\mathrm{b}} k_{\mathrm{COD}}$ : pseudo-first-order rate constant based on the degradation of COD in solution.

${ }^{c} k_{\text {TOC }}$ : pseudo-first-order rate constant based on the degradation of TOC in solution.

\section{Conclusions}

Solar energy could be concentrated efficiently by using Fresnel lens and had a significant effect on the increase of $\mathrm{UV}_{280-400 \mathrm{~nm}}$ light intensity of solar irradiation and the temperature of wastewater, leading to a positive effect on the performance of solar photocatalytic process. A biodegradability of 0.15 and a COD degradation of $27.4 \%$ and a TOC degradation of $25.8 \%$ of color filter wastewater were achieved in $1 \mathrm{~h}$ reaction under the reaction conditions of an initial $\mathrm{pH}$ of 7.5, a $\mathrm{TiO}_{2}$ concentration of $1.5 \mathrm{~g} / \mathrm{L}$, and an assistance of Fresnel lens. Consequently, the solar $\mathrm{TiO}_{2}$ photocatalytic process with the use of a PMMA Fresnel lens can offer an economical and practical alternative for the pretreatment of color filter wastewater towards biodegradable, making color filter wastewater be treated effectively by a biological process possible.

\section{Acknowledgments}

Many thanks to the kind sponsorship of National Science Council, Taiwan (Project no.: NSC 98-2221-E-239-004), without which this work would not have been possible.

\section{References}

[1] F. Al Momani, "Impact of photo-oxidation technology on the aqueous solutions of nitrobenzene: degradation efficiency and biodegradability enhancement," Journal of Photochemistry and Photobiology A, vol. 179, no. 1-2, pp. 184-192, 2006.

[2] L. A. Pérez-Estrada, S. Malato, A. Agüera, and A. R. Fernández-Alba, "Degradation of dipyrone and its main intermediates by solar AOPs. Identification of intermediate products and toxicity assessment," Catalysis Today, vol. 129, no. 1-2, pp. 207-214, 2007.
[3] M. I. Maldonado, P. C. Passarinho, I. Oller et al., "Photocatalytic degradation of EU priority substances: a comparison between $\mathrm{TiO}_{2}$ and Fenton plus photo-Fenton in a solar pilot plant," Journal of Photochemistry and Photobiology A, vol. 185, no. 2-3, pp. 354-363, 2007.

[4] S. Malato, P. Fernández-Ibáñez, M. I. Maldonado, J. Blanco, and W. Gernjak, "Decontamination and disinfection of water by solar photocatalysis: recent overview and trends," Catalysis Today, vol. 147, no. 1, pp. 1-59, 2009.

[5] J.-C. Sin, S.-M. Lam, A. R. Mohamed, and K.-T. Lee, "Degrading endocrine disrupting chemicals from wastewater by $\mathrm{TiO}_{2}$ photocatalysis: a review," International Journal of Photoenergy, vol. 2012, Article ID 185159, 23 pages, 2012.

[6] J. A. Byrne, P. A. Fernandez-Ibañez, P. S. M. Dunlop, D. M. A. Alrousan, and J. W. J. Hamilton, "Photocatalytic enhancement for solar disinfection of water: a review," International Journal of Photoenergy, vol. 2011, Article ID 798051, 12 pages, 2011.

[7] M. S. T. Gonçalves, E. M. S. Pinto, P. Nkeonye, and A. F. Oliveira-Campos, "Degradation of C.I. Reactive Orange 4 and its simulated dyebath wastewater by heterogeneous photocatalysis," Dyes and Pigments, vol. 64, no. 2, pp. 135-139, 2005.

[8] A. Durán and J. M. Monteagudo, "Solar photocatalytic degradation of reactive blue 4 using a Fresnel lens," Water Research, vol. 41, no. 3, pp. 690-698, 2007.

[9] G. E. P. Box, W. G. Hunter, and J. S. Hunter, Statistics For Experimenters: An Introduction to Design, Data Analysis and Model Building, Wiley, New York, NY, USA, 1st edition, 1978.

[10] APHA, AWWA, and WEF, Standard Methods For the Examination of Water and Wastewater, American Public Health Association, Washington, DC, USA, 20th edition, 2000.

[11] E. Evgenidou, K. Fytianos, and I. Poulios, "Semiconductorsensitized photodegradation of dichlorvos in water using $\mathrm{TiO}_{2}$ and $\mathrm{ZnO}$ as catalysts," Applied Catalysis B, vol. 59, no. 1-2, pp. 81-89, 2005.

[12] G. Li, X. S. Zhao, and M. B. Ray, "Advanced oxidation of orange II using $\mathrm{TiO}_{2}$ supported on porous adsorbents: the role of $\mathrm{pH}, \mathrm{H}_{2} \mathrm{O}_{2}$ and $\mathrm{O}_{3}$," Separation and Purification Technology, vol. 55, no. 1, pp. 91-97, 2007.

[13] Y. Zhang, J. Wan, and Y. Ke, "A novel approach of preparing $\mathrm{TiO}_{2}$ films at low temperature and its application in photocatalytic degradation of methyl orange," Journal of Hazardous Materials, vol. 177, no. 1-3, pp. 750-754, 2010.

[14] Q. Xiang, J. G. Yu, and M. Jaroniec, "Tunable photocatalytic selectivity of $\mathrm{TiO}_{2}$ films consisted of flower-like microspheres with exposed $\{001\}$ facets," Chemical Communications, vol. 47, no. 15, pp. 4532-4534, 2011.

[15] D. Wang, J. Zhang, Q. Luo, X. Li, Y. Duan, and J. An, "Characterization and photocatalytic activity of poly(3-hexylthiophene)-modified $\mathrm{TiO}_{2}$ for degradation of methyl orange under visible light," Journal of Hazardous Materials, vol. 169, no. 1-3, pp. 546-550, 2009.

[16] J. M. Monteagudo, A. Durán, J. Guerra, F. García-Peña, and P. Coca, "Solar $\mathrm{TiO}_{2}$-assisted photocatalytic degradation of IGCC power station effluents using a Fresnel lens," Chemosphere, vol. 71, no. 1, pp. 161-167, 2008.

[17] B. Cheng, Y. Le, W. Q. Cai, and J. G. Yu, "Synthesis of hierarchical $\mathrm{Ni}(\mathrm{OH})_{2}$ and $\mathrm{NiO}$ nanosheets and their adsorption kinetics and isotherms to Congo red in water," Journal of Hazardous Materials, vol. 185, no. 2-3, pp. 889-897, 2011.

[18] N. Barka, A. Assabbane, A. Nounah, J. Dussaud, and Y. A. Ichou, "Photocatalytic degradation of methyl orange with immobilized $\mathrm{TiO}_{2}$ nanoparticles: effect of $\mathrm{pH}$ and some inorganic anions," Physical and Chemical News, vol. 41, pp. 85-88, 2008 . 
[19] M. S. T. Gonçalves, A. M. F. O. Campos, E. M. M. S. Pinto, P. M. S. Plasência, and M. J. R. P. Queiroz, "Photochemical treatment of solutions of azo dyes containing $\mathrm{TiO}_{2}$," Chemosphere, vol. 39, no. 5, pp. 781-786, 1999.

[20] Y. C. Hsu, H. C. Yang, and J. H. Chen, "The enhancement of the biodegradability of phenolic solution using preozonation based on high ozone utilization," Chemosphere, vol. 56, no. 2, pp. 149-158, 2004

[21] D. Gumy, C. Morais, P. Bowen et al., "Catalytic activity of commercial of $\mathrm{TiO}_{2}$ powders for the abatement of the bacteria (E. coli) under solar simulated light: influence of the isoelectric point," Applied Catalysis B, vol. 63, no. 1-2, pp. 76-84, 2006.

[22] C. C. Liu, Y. H. Hsieh, P. F. Lai, C. H. Li, and C. L. Kao, "Photodegradation treatment of azo dye wastewater by $\mathrm{UV} / \mathrm{TiO}_{2}$ process," Dyes and Pigments, vol. 68, no. 2-3, pp. 191-195, 2006.

[23] N. Daneshvar, M. Rabbani, N. Modirshahla, and M. A. Behnajady, "Kinetic modeling of photocatalytic degradation of Acid Red 27 in $\mathrm{UV} / \mathrm{TiO}_{2}$ process," Journal of Photochemistry and Photobiology A, vol. 168, no. 1-2, pp. 39-45, 2004.

[24] N. Barka, A. Assabbane, A. Nounah, and Y. A. Ichou, "Photocatalytic degradation of indigo carmine in aqueous solution by $\mathrm{TiO}_{2}$-coated non-woven fibres," Journal of Hazardous Materials, vol. 152, no. 3, pp. 1054-1059, 2008.

[25] Y. C. Lin and H. S. Lee, "Effects of $\mathrm{TiO}_{2}$ coating dosage and operational parameters on a $\mathrm{TiO}_{2} / \mathrm{Ag}$ photocatalysis system for decolorizing Procion red MX-5B," Journal of Hazardous Materials, vol. 179, no. 1-3, pp. 462-470, 2010.

[26] Q. J. Xiang, J. G. Yu, and P. K. Wong, "Quantitative characterization of hydroxyl radicals produced by various photocatalysts," Journal of Colloid and Interface Science, vol. 357, no. 1, pp. 163-167, 2011.

[27] G. L. Newton and J. R. Milligan, "Fluorescence detection of hydroxyl radicals," Radiation Physics and Chemistry, vol. 75, no. 4, pp. 473-478, 2006. 


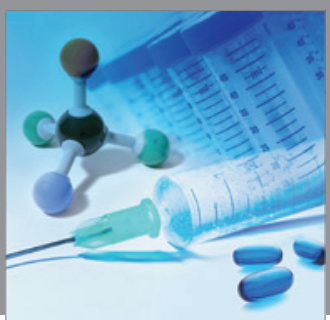

International Journal of

Medicinal Chemistry

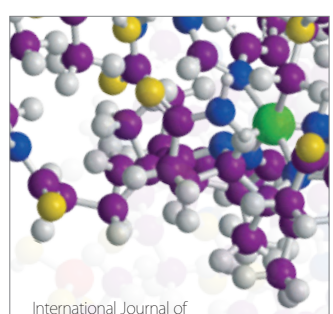

Carbohydrate Chemistry

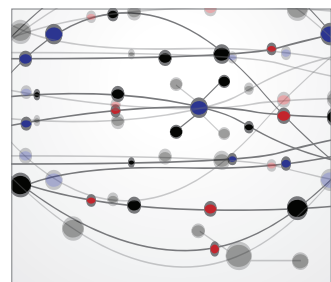

The Scientific World Journal
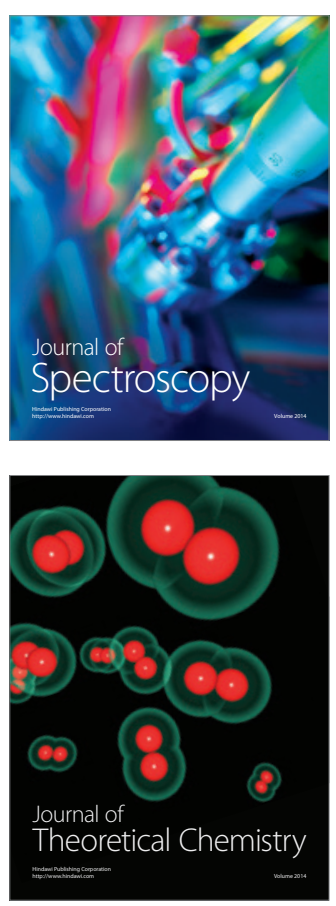
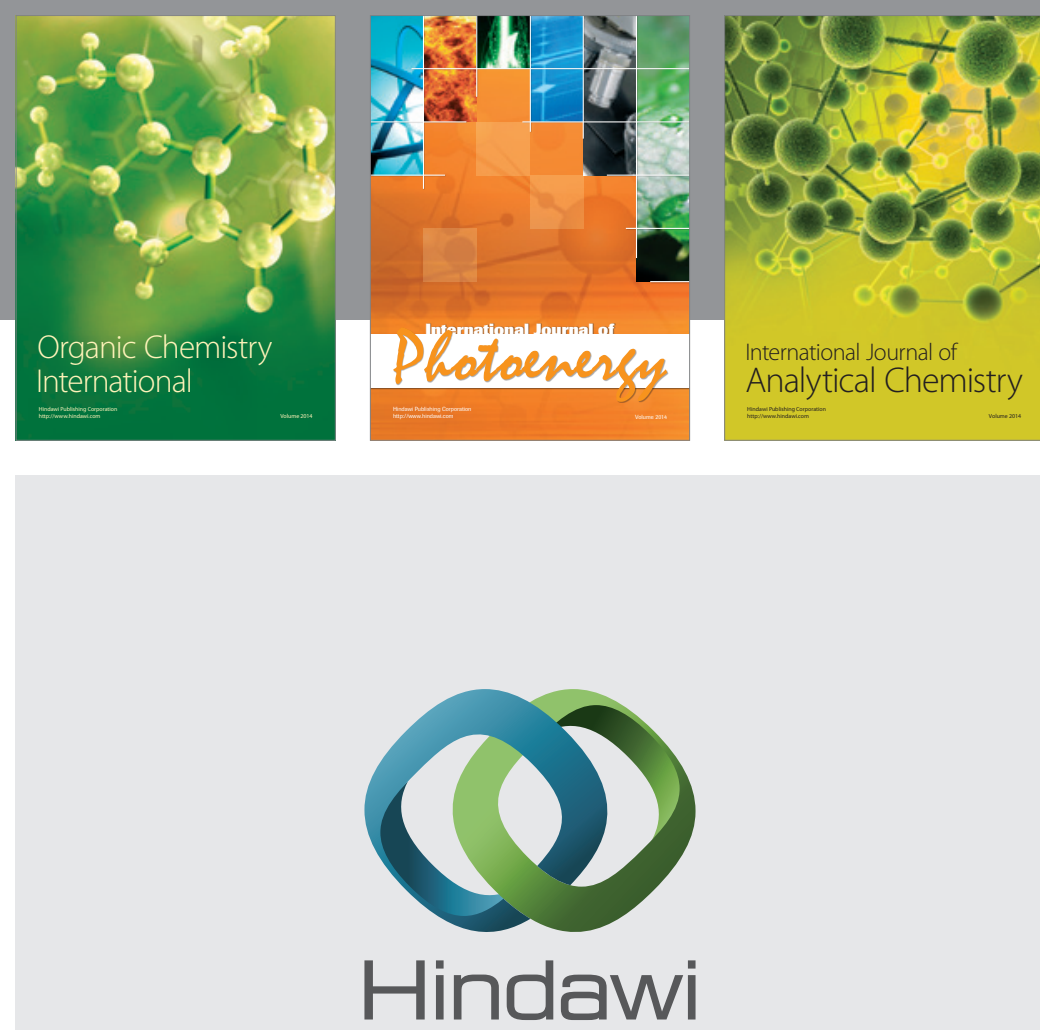

Submit your manuscripts at

http://www.hindawi.com
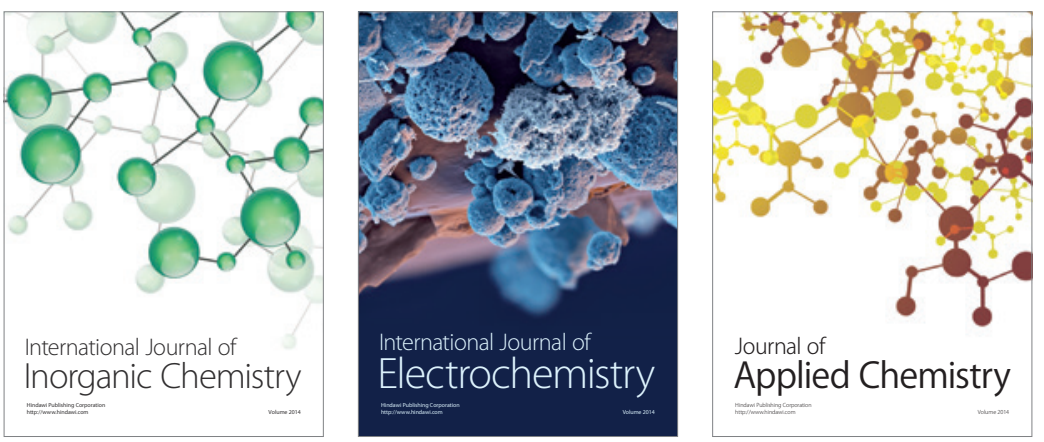

Journal of

Applied Chemistry
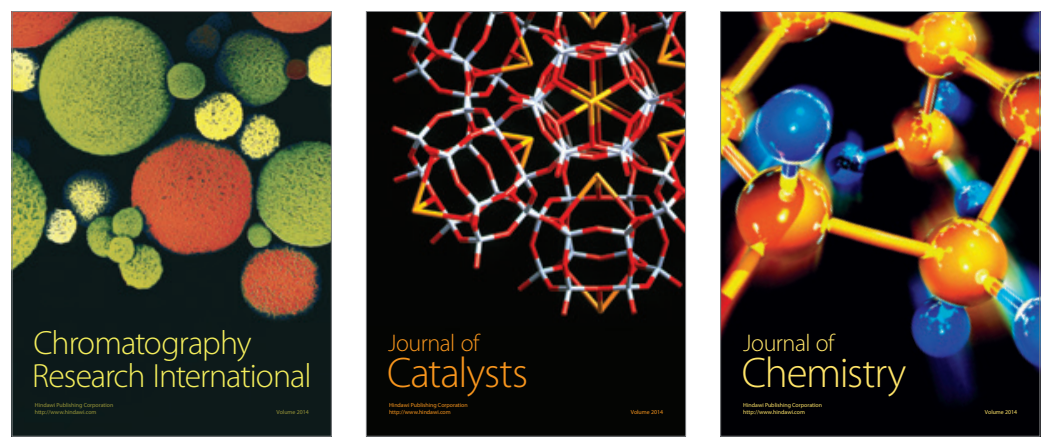
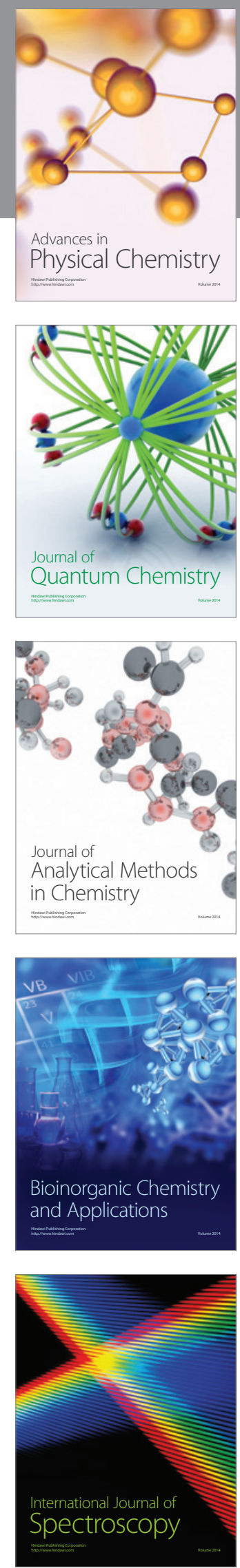